\title{
Europe in local news
}

\author{
MURIEL C. PLUSCHKE \\ Fulda University of Applied Sciences, Germany \\ muriel.pluschke@sk.hs-fulda.de
}

\begin{abstract}
Local newspapers are rarely in the focus of research on the European public sphere. However, due to their various democratic functions, they should not be neglected and may help to build a European public sphere. This article presents the results of an in-depth study of local newspapers by asking: a) How and to what extent can local newspapers contribute to the construction of a European public sphere by Europeanisation of the local public through reporting on the EU? b) Which factors have an effect on how local newspapers report on EU topics? This paper synthesises theories and models of the European public to develop hypotheses, which are then tested in interviews with six local German journalists. It finds that local newspapers can promote the emergence of a European public sphere and that news factors, resources, individual attitudes and editorial frameworks do have an impact on their EU reporting.
\end{abstract}

Key words: EU reporting, European public sphere, Europeanisation, local/regional News, local journalists, local public, Germany

\section{Introduction}

The European Union (EU) is a recurring topic in German news media. Media reports on the EU have important functions for its democratic accountability and publicity, as media outlets hold crucial critique and control functions, mediate between political decision makers and the public and may be able to help build a European public sphere (Altmeppen \& Greck, 2012, pp. 111-112; Eder, Hellmann \& Trenz., 1998, pp. 321-322; Eilders \& Voltmer, 2003, p. 251). However, not only national newspapers report on European topics but also local newspapers, covering cities, municipalities and regions of various sizes, which have more readers than the national quality press in Germany (Pasquay, 2017, p. 15). Given the media's functions for the EU's accountability and publicity, local newspapers are crucially relevant for the legitimacy of European policy and decisionmaking processes. Surprisingly, they have so far been neglected in research and scholars have focused, instead, on national quality newspapers (Hepp, Brüggemann, Kleinen-v.Königslöw, Lingenberg \& Möller, 2012, p. 54; Machill, Beiler \& Fischer, 2006, p. 140; Möhring, 2015, p. 12, 36, 64-66).

Based on the assumption that a European public sphere can emerge by Europeanisation ${ }^{1}$ of national or local public spheres within member states, the leading research questions

\footnotetext{
${ }^{1}$ Europeanisation refers to the impacts of the process of European Integration, which describes the development of European politics and institutions on national structures, processes and actors (Eising 2006, p. 396).
} 
of this empirical study are: How and to what extent can local newspapers contribute to the construction of a European public sphere by Europeanisation of the local public through reporting on the EU? Which factors have an effect on how local newspapers report on EU topics?

To answer both research questions, this study combines different theories and models of the European public sphere with scientific findings on local journalism and theories of news selection. Taken together, this paper processes the findings, develops a research design and establishes heuristic links by form of hypotheses. The study seeks to verify and develop the hypotheses empirically by interviewing six journalists from German local newspapers.

This paper will briefly summarise the theoretical framework and the hypotheses. Subsequently, it will summarise the procedure and results of the empirical analysis. The conclusion will provide a summary and an outlook.

\section{A European public space: state of the art in research}

Public spheres function to mediate between the opinions and interests of citizens, collective actors in society and the political system (Gerhards \& Neidhardt, 1990). Gerhards and Neidhardt (1990, p. 12, 17) regard them as intermediary systems and highlight their openness to everyone and their orientation towards the general public. Public spheres, generally and with regard to the EU, are deeply interwoven with democracy and are a basic requirement for democratic decision-making (Peters, 2003, p. 444). Furthermore, they go hand in hand with the democratic and public deficit of the EU (Gerhards, 2000, p. 292; Rohrer, 2010, p. 69). Theories of democracy and approaches to the development of a European public can be differentiated into a liberal-representative and a deliberative approach (Gerhards, 1997). This paper draws on the former as it focuses on the visibility of mass media and structural conditions. Transparency is highlighted in this approach. It consists of a passive right to information as well as an active requirement for institutions to provide information (Rohrer, 2010, p. 71).

In addition, three main models on how a European public sphere can emerge are mentioned in research. These are not mutually exclusive, but may complement each other (Trenz, 2003, p. 162). They consist in a pan-European public sphere, segmented transnational themed public spheres and the Europeanisation of national public spheres (Eilders \& Voltmer, 2003, pp. 251-254). The latter, referred to in this study, can be divided into a vertical (national and the European level) and a horizontal (between member states) dimension (Pfetsch, 2004, p. 5). Also, Europeanisation may vary depending on the policy field and the types of EU jurisdiction (Pfetsch, 2004, p. 5, pp. 6061). In the literature, various factors are deemed necessary for the formation of a European public sphere, such as the discussion of the same European topics at the same time and at the same level of attention or the use of similar frameworks of reference and patterns of interpretation (Risse \& Van de Steeg, 2003, p. 2). However, it has to be noted that there are no scales and criteria or limits to measure (sufficient) degrees of Europeanisation (Eilders \& Voltmer, 2004, p. 364; Machill, Beiler \& Fischer, 2006, p. 150).

The mass media take on a central mediating function in the exchange of information between citizens and political decision-makers (Eilders \& Voltmer, 2003, p. 251). Their function is to select and report on events, to define them in thematic agendas, to interpret themes and topics and to create a public (Kambeck, 2004, pp. 49-51; Schulz, 2011, p. 32). 
As such, they are the citizen's most important source of information about (EU) politics and able to provide a permanent observation of politics (Gerhards, 2000, p. 287; 2002, p. 3). Local media in particular provide important democratic means for orientation and for participation (Nazarewska, 2014, pp. 82-83).

However, mass media can neither represent reality holistically nor reflect it exactly, since they have to choose - using various selection criteria - from a wide range of information when selecting topics and news (Engelmann, 2016; Reese and Shoemaker, 2016; Schulz, 2011, p. 67). It follows that mass media takes on a dual role by mediating between politicians and citizens and by shaping political discourse through their selection process. Therefore, some scholars have argued that mass media can also be viewed as independent political actors (Eilders \& Lüter, 1998, p. 2; Eilders \& Voltmer, 2003, p. 251). Likewise, journalists assume a dual role as they convey statements made by other actors but also act as political speakers themselves (Tobler, 2010, p. 39). Furthermore, the mass media take on an agenda-setting function and are able to influence the "salience of attitudes toward the political issues” (McCombs \& Shaw, 2017, p. 106, p. 113).

\section{Building hypotheses by connecting theories}

By drawing on the theoretical background, this paper links the different strands of theory to formulate hypotheses as follows:

\section{Local newspapers contribute to the emergence of a European public sphere}

Theories of the European public ascribe a central role to mass media and emphasise that their voice as mediator and speaker is of high importance in the Europeanisation of public communication (Pfetsch \& Koopmans, 2006, pp.179-181). EU reporting in local newspapers and their references to Europe are said to carry the potential to involve citizens in the output of EU policies. They further offer means for interaction and for providing orientation to create a European identity. The literature emphasises that local news enable "access to the importance of EU policy decisions for one's own life" (Liebetruth, 2012, pp. 20-30, p. 43, pp. 68-70, own translation) and can help to involve citizens in the in- and output of European politics. Furthermore, public communication processes at the local, national and European level are fundamental to the legitimacy of political decision-making processes (Pfetsch \& Koopmans, 2006, p. 179) more broadly. In consequence, it can be assumed that through reporting, local newspapers not only contribute to the emergence of a local public sphere, but through an increased uptake of European issues and the involvement of European actors, also contribute to its Europeanisation.

\section{Local newspapers play a key role in communicating information}

Local newspapers can provide information, make topics visible and break them down, explain contexts and reduce complexity (Golombek, 2012; Möhring, 2017, pp. 3-4). On an individual level, surveys of journalists show that they view their role along similar lines. Journalists predominantly mention the rapporteur's addressing type, who depicts political events in a compact manner, and the processors, who process political developments (Hepp, Brüggemann, Kleinen-v.-Königslöw, Lingenberg \& Möller, 2012, pp.173-177). Providing information is regarded as the most important task of local newspapers and the mediation between politics and citizens is of great importance (Bannasch, 2003, pp. 89-90). It follows that local newspapers can play the mass media's 
key role at a local level and consider themselves responsible for selecting, providing and conveying information. However, local journalism is often criticised for being uncritical, not claryfing context and lacking and detailed analysis, all of which may negatively affect the local medias' functions (Arnold \& Wagner, 2018, p. 195; Kretzschmar, Möhring \& Timmermann, 2009, p. 54).

\section{Individual views of journalists as well as the editorial line have effects on EU reporting in local newspapers}

The mass media's dual role is particularly important, as local journalists have greater freedom in the subjective setting of topics and individual opportunities to influence reporting (Nazarewska, 2014, p. 9, 126). Their personal interests and values, the meanings ascribed to certain facts or political opinions but also processes and structures in the editorial offices and the editorial line are, therefore, relevant (Kepplinger, 2011, p. 79; Östgaard, 1965, p. 44). In Germany pro-European reporting is dominant and some scholars have referred to German media as motors of Europeanisation (Huber, 2012, p. 124; Pfetsch \& Koopmans, 2006, p. 190).

\section{When choosing news and topics related to the EU in local newspapers various news factors are effective}

News factors, which are characteristics of an event and provide an "unspoken set of rules which are learned on the job and become central to journalists' ways of life", are relevant because they have a strong impact on international reporting and news about the EU are largely reported in the foreign policy section (Eilders, 2006, p. 258, 2016, p. 431; Huber, 2012, p. 124; Wahl-Jorgensen, 2014, p. 315). Empirically, evidence suggests factors such as "relevance/range, damage, controversy, elite people and thematization" (Eilders, 2016, p. 435, own translation). In addition, the literature considers the factors 'personalisation', 'short duration' and 'proximity' as particularly important for local newspapers (Liebetruth, 2012, pp. 71-76; Möhring, 2015, p. 26). But researchers argue there aredeficits with regard to the media's attention to the EU, and EU politics is often considered unsuitable for the above "criteria of media selectivity" due to its complexity often requiring further elaboration (Eder \& Kantner, 2000, p. 313, own translation; Gerhards, 2000, pp. 297-300).

\section{Intermedia agenda setting and news agencies influence the horizontal Europeanisation}

Intermedia agenda setting, in which certain leading media are viewed as pioneers, as well as the orientation shown by other media outlets and colleagues are possible across member states borders and thus may contribute to alignments in reporting and horizontal Europeanisation (Schulz, 2011, p. 110). Additionally, various news agencies or EU correspondents in Brussels are active in different member states at the same time by working for different national and local media outlets and can, therefore, influence them simultaneously (Liebetruth, 2012, pp. 88-89).

\section{EU reporting in local newspapers}

The empirical analysis is based on interviews with six journalists from medium-sized German local newspapers. They provide insights into personal and individual characteristics as well as the context of their work, institutional structures and additional 
external influences. An interview-based approach also allows for an examination of psychological factors, which is difficult to determine through content analysis or observations. However, it must be noted that their statements are subjective assessments and may be influenced by their personal views, therefore, they cannot be regarded as completely reliable and valid (Engelmann, 2016, pp. 43-48). The expert interviews with journalists were conducted as semi-structured interviews by drawing on a prepared list of open-ended questions. The interviews lasted between 30 to 60 minutes across three subject areas, which dealt with general questions, EU reporting and the resources the journalists draw on.

The criteria for the selection of interviewees included that print editions of the newspapers were published on weekdays, optionally on Saturdays and that they had both a mantle ${ }^{2}$ and specifically local sections. Their websites, social media channels or numbers of print copies were not taken into consideration. In terms of content, the newspapers reported on European topics among other things in their political, economic or cultural sections and in local sections on, for example, agricultural or EU-funding issues. Six journalists working in leading positions in the central or local editorial offices of local newspapers agreed to be interviewed: Kinzigtal-Nachrichten, Fuldaer Zeitung, Neue Westfälische, Westfalen-Blatt and Mediengruppe Thüringen. It should be noted that the qualitative analysis is based on these six interviews and does not constitute a representative sample of all German regions and local newspapers. The sample size thus may impact the generalisability of the findings.

The interviews were recorded, transcribed, and then evaluated using qualitative interview analysis, a method that enables a systematic reduction of information by using the software MAXQDA. In a first step the interviews were coded by assigning categories to text passages (Gläser \& Laudel, 2010, pp. 199-201). The research process established codes and categories beforehand based on the literature, such as 'news factors' and 'personalisation' and in the process of coding, such as 'partner cities' or 'banal Europeanism' (Kelle \& Kluge, 2010, p. 59). For a comparative analysis, all categories were cross-checked against the final interview transcripts. 3 The empirical analysis enabled verification, development and creation of new hypotheses. 4

\section{Local newspapers contribute to the emergence of a European public sphere}

The interviews with the journalists confirm the first hypothesis. There is agreement among journalists that EU reporting is important and that it is necessary to inform and educate readers about European issues. The interviewees also reported that their colleagues tend to agree on the need for EU reporting, partly encouraged by editorials or messages from editors-in-chief. One interviewee also stressed that the EU should be a focal point of reporting in local newspapers.

In terms of their perceived responsibility, the interviewees mentioned tasks related to democracy, the (European) elections and their function as mediators. They sometimes even consider the creation of a public sphere as one of their tasks, although the interviewees were not entirely sure about their possible contribution to a European public

\footnotetext{
${ }^{2}$ The mantle section is the part of a local newspaper which is the same for all the various regions. Local sections in contrast will consist of different articles according to where they are published.

3 The author can provide the codebook upon request.

4 In the following, own translations for direct citations will be used as the interviews were all conducted in German.
} 
sphere. It remains unclear to them, whether local newspapers are able to contribute to it, what their scope of influence is and whether their work is sufficient.

\section{Local newspapers play a key role in communicating information}

The interviews also confirm the second hypothesis. The journalists argue that to inform about Europe, to present facts and background information, to explain, classify and comment on complex EU issues, is a critical part of their role. One journalist even describes EU reporting as a "mirror of society", although the interviewee similarly cautions that journalists have to strike a balance between mainstream reporting and giving space to marginal issues and marginalised voices (Interview 3). In addition, they see it as their task to illuminate, critically evaluate and transparently inform about the processes at the European level (Interview 4). In terms of the criticism directed at local newspapers, the journalists emphasise that self-presentations, advertising and public relations have no place in local newspapers except for the editorial parts (Interview $1 ; 6$ ). Furthermore, they highlight the need for critical thinking, which one journalist describes as "basic distrust" (Interview 2; 4; 6). At the same time, the interviewees recognise limitations and difficulties in being able to carry out independent research and find some processes or information difficult to understand (Interview 2; 6; 3).

\section{Individual views of journalists as well as the editorial line have effects on EU reporting in local newspapers}

In the six interviews, journalists considered themselves as Europe-friendly or having a pro-European attitude, similar to their local newspapers more generally. They thus find that individual and editorial views and opinions shape how they report on the EU. However, all journalists note differences, for example in their available resources, such as dedicated correspondents or personal contacts. One journalist points out that it is necessary to have someone who cares about extensively reporting on the EU and thus shows initiative and "passion" ("Herzblut") (Interview 4). From the interviews it follows that local newspapers not only act as intermediaries and chroniclers, but also as independent actors as they sometimes seek to exert targeted influence with their formats, their ideas for EU reporting and their emphasis on EU topics.

\section{When choosing news and topics related to the EU in local newspapers various news factors are effective}

When asked about news factors, journalists repeatedly name factors such as 'personalisation', 'conflict', 'damage' and 'visuality', although the significance they attribute to these factors varies. The interviewees consider 'proximity' and 'relevance' as particularly important. One journalists points out that the EU is always reported on, in the foreign policy section and that the national aspect remains in the foreground (Interview 1). Another interviewee highlights that it is necessary for a topic to be locally relevant, or as being of local concern (Interview 3). Moreover, the interviewees find that the appearance of local actors such as farmers, local politicians or citizens facilitates reporting on the EU. However, they also mention deficits of EU topics regarding the existence of news factors, describe EU issues as complex, abstract or difficult and highlight the need for further clarification (Interview $3 ; 4 ; 5)$. Furthermore, they do not report with equal intensity on all policy fields and tend to exclude very theoretical topics or debates. 


\section{Intermedia agenda setting and news agencies influence the horizontal Europeanisation}

All journalists varied in responses that indicated their use of resources. First, interviewees mention other media, such as radio, television, social media or other newspapers and colleagues as potential sources. However, there seems to be no institutionalised, regular exchange (Interview 1; 2). They further highlight that while there is no exchange across member states, partly owing to language barriers (Interview $4 ; 5 ; 1 ; 2$ ), all journalists find developments in other member states more relevant and noteworthy than in non-EU countries (Interview 2; 4; 5). The interviewees consider news agencies as either important or as having only limited influence on their EU reporting. The same applies to correspondents, as not all newspapers share equal access and resources. Interview responses also mention members of the European Parliament and twin cities, which might indicate that closer contact can facilitate horizontal Europeanisation.

\section{Using the internet, local newspapers get into touch with more readers, intensify contact with them and further promote a public sphere}

One additional hypothesis was added based on the interviews. When asked about the role of the internet, the local newspaper journalists highlight expanded possibilities, e.g. options for new formats, but also the rising pressure to be continuously up-to-date. The latter leads to the print edition becoming more focused on the contextual aspects of a news item while important short news are published online immediately. The interviewees believe that online news will focus less on EU issues and that local and regional information will remain the focus (Interview $1 ; 5 ; 2$ ). While online news thus enable accessibility and publicity, they may not enable Europeanisation, since they are less likely to feature EU topics. Furthermore, a potential generational gap has to be taken into account because younger generations tend to not read print as much as older ones and require slightly different content and content presentation. This may also lead to the emergence of policy and issue-specific sub-publics as print and online reporting have different target groups (Interview 5). Overall, the internet offers the opportunity to reach more readers, to intensify and customise contact and content and, lastly, to promote the emergence and Europeanisation of the public sphere. However, this would require an increased number of online publications on EU topics.

\section{Conclusion}

This paper asked firstly, how and to what extent local newspapers' EU reporting contributes to the construction of a European public sphere through Europeanisation of the local public. The findings in this paper indicate that local newspapers may be able to promote the emergence of a European public sphere, as local journalists recognise their democratic function and responsibility. At the same time, they highlight a perpetual need of reporting on EU topics and the sensitisation of readers, the need for criticism and critical approaches as well as neutrality for exploring EU issues from all angles.

In response to the second research question - which factors have an effect on the reporting on EU topics in local newspapers? - journalists find that different news factors, especially 'proximity' and 'relevance', available resources, individual attitudes and editorial frameworks have an impact on EU reporting. To be sure, the local newspapers under examination here, share predominantly pro-European attitudes. However, journalists stress that there is hardly any cross-member-state exchange, which is why horizontal 
Europeanisation and thematic approximation appear less likely at a European than on a national level.

It should be noted that the empirical development of the hypotheses is based on six interviews only. Due the small sample size, the question regarding differences in reporting on the EU by local newspapers remains open and should be subject to further research. Furthermore, differences in interviewees' responses illustrate the difficulties for a generalisation of results. However, the findings provide important first insights and indications of where to conduct further research and why EU reporting in the local is important for European public spheres.

Further research could expand on the empirical analysis, for example by increasing the number of interviews or by cross-country comparative research to analyse countryspecific similarities and differences. One could also focus on the relevance of demographic factors of readers and audiences, as it is possible that generational narratives of Europe differ in member states.

\section{References}

Altmeppen, K.-D., \& Greck, R. (Eds.) (2012). Facetten des Journalismus: Theoretische Analysen und empirische Studien. VS Verlag für Sozialwissenschaften | Springer Fachmedien Wiesbaden GmbH.

Arnold, K., \& Wagner, A.-L. (2018). Die Leistungen des Lokaljournalismus: Eine empirische Studie zur Qualität der Lokalberichterstattung in Zeitungen und Onlineangeboten. Publizistik, 63(2), 177-206. https://doi.org/10.1007/s11616018-0422-4

Bannasch, K. (Ed.) (2003). Journalismus ohne Eigenleistung? Das Zustandekommen von Nachrichten in lokalen Medien. Zugl.: Stuttgart, Univ., Magisterarbeit, 2002. Ibidem.

Eder, K., Hellmann, K.-U., \& Trenz, H.-J. (1998). Regieren in Europa jenseits öffentlicher Legitimation? Eine Untersuchung zur Rolle von politischer Öffentlichkeit in Europa. In B. Kohler-Koch (Ed.), Regieren in entgrenzten Raumen.: Politische Vierteljahresschrift, Sonderheft 29 (pp. 321-344). Westdeutscher Verlag.

Eder, K., \& Kantner, C. (2000). Transnationale Resonanzstrukturen in Europa. Eine Kritik der Rede vom Öffentlichkeitsdefizit. In M. Bach (Ed.), Kölner Zeitschrift für Soziologie und Sozialpsychologie Sonderheft: Vol. 4o. Die Europäisierung nationaler Gesellschaften (pp. 306-331). Westdeutscher Verlag.

Eilders, C. (2006). Nachrichtenauswahl. In U. Hasebrink (Ed.), Medien von A bis $Z$ (1st ed., pp. 256-259). VS Verlag für Sozialwissenschaften | Springer Fachmedien Wiesbaden GmbH.

Eilders, C. (2016). Journalismus und Nachrichtenwert. In M. Löffelholz \& L. Rothenberger (Eds.), Handbuch Journalismustheorien (1st ed., pp. 431-442). Springer Fachmedien.

Eilders, C., \& Lüter, A. (1998). Methodenbericht zum Projekt: Die Stimme der Medien im politischen Prozeß - Themen und Meinungen in Pressekommentaren: 
Veröffentlichungsreihe der Abteilung Öffentlichkeit und soziale Bewegungen des Forschungsschwerpunktes Sozialer Wandel, Institutionen und

Vermittlungsprozesse des Wissenschaftszentrums Berlin für Sozialforschung.

Wissenschaftszentrum Berlin für Sozialforschung gGmbH (WZB).

http://userpage.fu-

berlin.de/ sgiel/WS_2003_o4_Methoden/Arbeitsmaterialien/FSIII_98-107.pdf

Eilders, C., \& Voltmer, K. (2003). Zwischen Deutschland und Europa. Eine empirische

Untersuchung zum Grad von Europäisierung und Europa-Unterstützung der meinungsführenden deutschen Tageszeitungen. Medien \&

Kommunikationswissenschaft, 51(2), 250-270. https://doi.org/10.5771/1615634X-2003-2-250

Eilders, C., \& Voltmer, K. (2004). Zwischen Marginalisierung und Konsens: Europäische Öffentlichkeit in Deutschland. In C. Eilders, F. Neidhardt, \& B. Pfetsch (Eds.), Die Stimme der Medien: Pressekommentare und politische Öffentlichkeit in der Bundesrepublik (1st ed., pp. 358-385). VS Verlag für Sozialwissenschaften | GWV Fachverlage GmbH.

Eising, R. (2006). Europäisierung und Integration: Konzepte in der EU-Forschung. In M. Jachtenfuchs \& B. Kohler-Koch (Eds.), Europäische Integration (2nd ed., pp. 387-416). VS Verlag für Sozialwissenschaften | GWV Fachverlage GmbH.

Engelmann, I. (2016). Gatekeeping (1. Auflage). Konzepte. Ansätze der Medien- und Kommunikationswissenschaft: Vol. 16. Nomos Verlagsgesellschaft mbH \& Co. KG. http://gbv.eblib.com/patron/FullRecord.aspx?p=4561596 https://doi.org/10.5771/9783845263533

Gerhards, J. (1997). Diskursive versus liberale Öffentlichkeit: Eine empirische Auseinandersetzung mit Jürgen Habermas. Kölner Zeitschrift Für Soziologie Und Sozialpsychologie, 49(1), 1-34.

https://www.researchgate.net/publication/343425835_Diskursive_versus_liber ale_Offentlichkeit_Eine_empirische_Auseinandersetzung_mit_Jurgen_Haberm as

Gerhards, J. (2000). Europäisierung von Ökonomie und Politik und die Trägheit der Entstehung einer europäischen Öffentlichkeit. In M. Bach (Ed.), Kölner Zeitschrift für Soziologie und Sozialpsychologie Sonderheft: Vol. 4O. Die Europäisierung nationaler Gesellschaften (pp. 277-305). Westdeutscher Verlag.

Gerhards, J. (2002). Das Öffentlichkeitsdefizit der EU im Horizont normativer Öffentlichkeitstheorien. Demokratiezentrum Wien. http://www.demokratiezentrum.org/fileadmin/media/pdf/gerhards_eu.pdf

Gerhards, J., \& Neidhardt, F. (1990). Strukturen und Funktionen moderner Öffentlichkeit: Fragestellungen und Ansätze. Veröffentlichungsreihe Der Abteilung Öffentlichkeit Und Soziale Bewegung Des Forschungsschwerpunkts Sozialer Wandel, Institutionen Und Vermittlungsprozesse Des Wissenschaftszentrums Berlin Für Sozialforschung. https://bibliothek.wzb.eu/pdf/1990/iii90-101.pdf (FS III 90-101).

Gläser, J., \& Laudel, G. (2010). Experteninterviews und qualitative Inhaltsanalyse als Instrumente rekonstruierender Untersuchungen (4. Auflage). Lehrbuch. VS 
Verlag für Sozialwissenschaften | Springer Fachmedien Wiesbaden GmbH. http://d-nb.info/1002141753/o4

Golombek, D. (2012, December 20). Mit Öffentlichkeit dienen: Der Demokratieauftrag der Lokalredaktion. http://www.bpb.de/gesellschaft/medien-undsport/lokaljournalismus/151167/mit-oeffentlichkeit-dienen

Hepp, A., Brüggemann, M., Kleinen-v.-Königslöw, K., Lingenberg, S., \& Möller, J. (2012). Politische Diskurskulturen in Europa: Die Mehrfachsegmentierung europäischer Öffentlichkeit. Medien - Kultur - Kommunikation. VS Verlag für Sozialwissenschaften | Springer Fachmedien Wiesbaden GmbH. http://dx.doi.org/10.1007/978-3-531-94324-4 https://doi.org/10.1007/978-3531-94324-4

Huber, C. K. (2012). Zwischen Routine, Ratspräsidentschaft und Gipfel: Interaktionen von Medien und Politik in der Europäischen Union. Zugl.: Hamburg Univ., FB Sozialwiss. Diss. 2011 u.d.T.: Huber, Claudia Kristine: Gezeiten der Aufmerksamkeit. VS Verlag für Sozialwissenschaften | Springer Fachmedien Wiesbaden GmbH.

Kambeck, M. (2004). Politikvermittlung auf EU- und Bundesebene - ein Vergleich in Theorie und Praxis unter besonderer Berücksichtigung des Politikfeldes Informationsgesellschaft. Inaugral-Dissertation zur Erlangung der Doktorwürde der Philosophischen Fakultät der Rheinischen Friedrich-Wilhelms-Universität zu Bonn.

Kelle, U., \& Kluge, S. (2010). Vom Einzelfall zum Typus: Fallvergleich und Fallkontrastierung in der qualitativen Sozialforschung (2., überarb. Aufl.). Qualitative Sozialforschung: Vol. 15. VS Verlag für Sozialwissenschaften | Springer Fachmedien Wiesbaden GmbH. http://deposit.dnb.de/cgibin/dokserv?id=2671651\&prov=M\&dok_var=1\&dok_ext=htm

Kepplinger, H. M. (2011). Journalismus als Beruf(1. Aufl.). Theorie und Praxis öffentlicher Kommunikation: Vol. 6. VS Verlag für Sozialwissenschaften | Springer Fachmedien Wiesbaden GmbH. http://dx.doi.org/10.1007/978-3-53192915-6 https://doi.org/10.1007/978-3-531-92915-6

Kretzschmar, S., Möhring, W., \& Timmermann, L. (Eds.). (2009). Kompaktwissen Journalismus. Lokaljournalismus (1. Aufl.). VS Verlag für Sozialwissenschaften | GWV Fachverlage GmbH. http://deposit.d-nb.de/cgibin/dokserv?id=2837190\&prov=M\&dok_var=1\&dok_ext=htm

Langenbucher, W. R., \& Latzer, M. (Eds.). (2006). Europäische Öffentlichkeit und medialer Wandel: Eine transdisziplinäre Perspektive. VS Verlag für Sozialwissenschaften | GWV Fachverlage GmbH. http://dx.doi.org/10.1007/9783-531-90272-2 https://doi.org/10.1007/978-3-531-90272-2

Liebetruth, D. (2012). Europa vor Ort verankern: Potenzial und journalistische Gestaltungsmöglichkeiten lokaler EU-Nachrichten in der regionalen Tagespresse ; eine Analyse mit Beispielen niedersächsischer Lokalzeitungen. Zugl.: Hannover, Hochsch. für Musik, Theater und Medien, Diss., 2011. Mensch und Buch Verlag. 
Machill, M., Beiler, M., \& Fischer, C. (2006). Europa-Themen in Europas Medien - die Debatte urn die europäische Öffentlichkeit.: Eine Metaanalyse medieninhaltsanalytischer Studien. In W. R. Langenbucher \& M. Latzer (Eds.), Europäische Öffentlichkeit und medialer Wandel: Eine transdisziplinäre Perspektive (pp. 132-155). VS Verlag für Sozialwissenschaften | GWV Fachverlage GmbH.

McCombs, M. E., \& Shaw, D. L. (2017). The Agenda-Setting function of mass media. The Agenda Setting Journal, 1(2), 105-117. https://doi.org/10.1075/asj.1.2.02mcc

Möhring, W. (2015). Lokaljournalismus im Fokus der Wissenschaft: Zum

Forschungsstand Lokaljournalismus - unter besonderer Berücksichtigung von

Nordrhein-Westfalen. Eine Expertise im Auftrag der Landesanstalt für Medien Nordrhein-Westfalen (LfM) (Auflage: 750). LfM-Dokumentation: Vol. 51.

Landesanstalt für Medien Nordrhein-Westfalen.

https://pdfdokument.com/lokaljournalismus-im-lfmpublikationen_59f3330a1723ddaf2d4a5bdo.html

Möhring, W. (02.30.2017). Vertrauensgut lokale Medien? Strukturen und Charakteristika lokaler medialer Öffentlichkeit in Nordrhein-Westfalen [Forschungspapier].

https://www.drehscheibe.org/files/drehscheibe/media/news/forschung/forschu ng/studie-vertrauensgut-lokale-medien-moehring.pdf

Nazarewska, B. (2014). Lokalfürsten der Regionalzeitung: Wer bestimmt die redaktionelle Nachrichtenauswahl im Lokalteil? Inaugural-Dissertation zur Erlangung des Doktorgrades der Philosophisch- Sozialwissenschaftlichen Fakultät der Universität Augsburg [Inaugural-Dissertation]. Universität Augsburg. https://opus.bibliothek.uniaugsburg.de/opus4/frontdoor/deliver/index/docId/3752/file/Diss_Nazarewska. pdf

Östgaard, E. (1965). Factors Influencing the Flow of News. Journal of Peace Research, 2(1), 39-63. https://doi.org/10.1177/002234336500200103

Pasquay, A. (2017). Die deutschen Zeitungen in Zahlen und Daten 2018. https://www.bdzv.de/fileadmin/bdzv_hauptseite/aktuell/publikationen/2017/Z DF_2017.pdf

Peters, B. (2003). Die Transnationalisierung von Öffentlichkeit und ihre Bedeutung für die politische Ordnung am Beispiel der EU. InllS-Projektantrag an die DFG. http://www.state.unibremen.de/download/de/forschung/B3_2003_projektantrag.pdf

Pfetsch, B. (2004). The Voice of the Media in European Public Sphere: Comparative Analysis of Newspaper Editorials. Integrated Report WP 3. http://europub.wzberlin.de

Pfetsch, B., \& Koopmans, R. (2006). Unter falschem Verdacht - Massenmedien und die Europäisierung der politischen Öffentlichkeit in Deutschland. In W. R. Langenbucher \& M. Latzer (Eds.), Europäische Öffentlichkeit und medialer Wandel: Eine transdisziplinäre Perspektive (pp. 179-191). VS Verlag für Sozialwissenschaften | GWV Fachverlage GmbH. 
Rohrer, M. (2010). Von der Konstruktion europäischer Öffentlichkeiten. Eine theoretische Einordnung der Kommunikationspolitik von Parlament und Kommission. In E. Klaus, C. Sedmak, R. Drüeke, \& G. Schweiger (Eds.), VS Research. Identität und Inklusion im europäischen Sozialraum (1st ed., 69-84). VS Research.

Schulz, W. (2011). Politische Kommunikation: Theoretische Ansätze und Ergebnisse empirischer Forschung (3., überarbeitete Auflage). VS Verlag für Sozialwissenschaften | Springer Fachmedien Wiesbaden GmbH. http://dx.doi.org/10.1007/978-3-531-93094-7 https://doi.org/10.1007/978-3531-93094-7

Tobler, S. (2010). Transnationalisierung nationaler Öffentlichkeit: Konfliktinduzierte Kommunikationsverdichtungen und kollektive Identitätsbildung in Europa. Zugl.: Zürich, Univ., Diss, 2009 (1. Aufl.). VS Verlag für Sozialwissenschaften | GWV Fachverlage GmbH. http://dx.doi.org/10.1007/978-3-531-92000-9 https://doi.org/10.1007/978-3-531-92000-9

Trenz, H.-J. (2003). Einführung: Auf der Suche nach einer europäischen Öffentlichkeit. In A. Klein, R. Koopmans, H.-J. Trenz, C. Lahusen, \& D. Rucht (Eds.), Bürgerschaft, Öffentlichkeit und Demokratie in Europa (pp. 161-168). Leske + Budrich.

Wahl-Jorgensen, K. (2014). The production of political coverage: The push and pull of power, routines and constraints. In C. Reinemann (Ed.), Handbooks of Communication Science /HoCS]: Vol. 18. Political Communication (305-323). Walter de Gruyter GmbH. 